\title{
PENGGUNAAN BAHASA DALAM IKLAN MINUMAN DI YOUTUBE
}

\author{
Ireneus Lyon Yuniman Bagut \\ SMP Katolik Santa Yosefa Labuan Bajo \\ bagutlyon@gmail.com
}

\begin{abstract}
Abstrak: Penelitian ini bertujuan untuk mendapatkan gambaran objektif tentang penggunaan bahasa dalam iklan minuman di youtube. Sehingga, rumusan masalah dalam penelitian ini, yaitu (1) bagaimana bentuk penggunaan bahasa dalam iklan minuman di youtube? (2) bagaimana fungsi penggunaan bahasa dalam iklan minuman di youtube? dan (3) bagaimana strategi penggunaan bahasa dalam iklan minuman di youtube? Penelitian ini menggunakan metode deskriptif kualitatif. Data dalam penelitian ini berupa kutipan kata, frase, dan kalimat tentang bentuk, fungsi, dan strategi penggunaan bahasa dalam iklan minuman di youtube. Sumber data dalam penelitian ini adalah iklan minuman di youtube. Teknik pengumpulan data dilakukan dengan dua cara yaitu teknik simak dan teknik catat. Sedangkan, teknik analisis data menggunakan model interaktif.Berdasarkan hasil analisis data, diperoleh temuan penelitian sebagai berikut. Pertama, bentuk penggunaan bahasa yang terdapat dalam iklan minuman di youtube adalah bentuk asertif dan direktif. Bentuk penggunaan bahasa yang dominan digunakan adalah bentuk asertif. Kedua, Fungsi penggunaan bahasa yang terdapat dalam iklan minuman di youtube adalah untuk menginformasikan, menyarankan, dan meyakinkan. Fungsi penggunaan bahasa yang dominan digunakan adalah berupa menginformasikan. Ketiga, strategi penggunaan bahasa yang terdapat dalam iklan minuman di youtube adalah strategi langsung dan tidak langsung. Strategi penggunaan bahasa yang dominan dipakai pengiklan adalah strategi tidak langsung.
\end{abstract}

Kata Kunci: penggunaan bahasa, iklan, minuman, youtube.

\section{LANGUAGE IN DRINK ADS ON YOUTUBE}

Abstract: This study aims to get an objective picture of language use in beverage advertisements on YouTube. So, the formulation of the problem in this study, namely (1) what is the form of language use in beverage advertisements on YouTube? (2) how is the function of language use in beverage advertisements on YouTube? and (3) what is the strategy for using language in beverage advertisements on YouTube? This study used descriptive qualitative method. The data in this study are in the form of words, phrases and sentences about the form, function, and strategy of using language in beverage advertisements on YouTube. The data source in this study is beverage advertisements on YouTube. Data collection techniques were carried out in two ways, namely refer to the note technique and note technique. Meanwhile, data analysis techniques use an interactive model. Based on the results of data analysis, the following research findings were obtained. First, the forms of language use contained in beverage advertisements on YouTube are assertive and directive forms. The dominant form of language used is assertive. Second, the function of using the language contained in drinks advertisements on YouTube is to inform, suggest, and 
convince. The function of using the dominant language used is in the form of informing. Third, the language use strategy contained in beverage advertisements on YouTube is a direct and indirect strategy. The dominant language use strategy used by advertisers is the indirect strategy.

Keywords: language usage, ads, drinking, youtube.

\section{PENDAHULUAN}

Sesuai dengan fungsi bahasa pada umumnya yaitu sebagai alat atau media komunikasi antar masyarakat. Bahasa sangat penting dalam setiap aktivitas manusia. Penggunaan bahasa merupakan salah satu cara untuk menyampaikan tuturan kepada mitra tutur di mana pun berada, baik dalam situasi formal maupun nonformal. Oleh karena itu, penggunaan bahasa dalam kehidupan sehari-hari disesuaikan dengan situasi dan kondisi tuturan.

Penggunaan bahasa yang baik merupakan penggunaan bahasa yang sesuai dengan situasi dan kondisi, sedangkan penggunaan bahasa yang benar adalah penggunaan bahasa yang sesuai dengan kaidah atau tata bahasa. Menurut Willing (2010:213) menyatakan bahwa penggunaan bahasa sebagai alat komunikasi, dikenal ragam bahasa lisan dan tulis. Keduanya terikat pada hukum-hukum, norma, aturan, kaidah, serta prinsip-prinsip dan sifat yang dimiliki bahasa yang digunakan. Tiap bahasa harus tunduk pada tata bahasa masing-masing. Sementara, menurut Suyanto (2015:31) menyatakan bahwa pembahasan tentang penggunaan bahasa tidak akan terlepas dari bahasa. Bahasa disebut juga ragam bahasa. Ragam bahasa adalah variasi bahasa yang pemakiannya berbeda-beda menurut topik yang dibicarakan antara hubungan pembicara, lawan bicara, dan orang yang dibicarakan, serta menurut media pembicara. Apabila kita berbicara kita menggunakan bahasa ragam lisan. Apabila kita menulis atau mengarang kita menggunakan bahasa tulis. Demikian pula halnya kita menggunakan bahasa Indonesia. Kita menggunakan bahasa Indonesia ragam lisan apabila kita berbicara dan kita menggunakan bahasa Indonesia ragam tulis apabila kita menulis (Effendi, 2012:5)

Berdasarkan pemikiran di atas, dapat disimpulkan bahwa penggunaan bahasa merupakan cara menggunakan bahasa yang sesuai dengan fungsi-fungsi bahasa agar mudah dipahami oleh pembaca atau pendengar. Penggunaan bahasa yang mudah dipahami adalah penggunaan bahasa yang baik dan benar. Atau dapat juga dikatakan bahwa penggunaan bahasa merupakan salah satu cara menyampaikan tuturan kepada orang lain dengan menggunakan bahasa sebagai alat komunikasinya.

Salah satu bidang dalam kehidupan yang tidak terlepas dari bahasa adalah pengiklanan (advertising). Iklan menggunakan bahasa sebagai sarana dalam mempromosikan sebuah komoditas (barang atau jasa) kepada masayarakat, baik secara tertulis maupun lisan. Iklan merupakan bentuk komunikasi yang bersifat persuasif dalam menawarkan barang atau jasa kepada masyarakat. Pengiklan membidik dari banyak sisi dalam memasarkan produknya kepada masyarakat. Ada beberapa hal yang perlu diperhatikan dalam memasarkan produk terutama dalam penggunaan bahasanya.Penggunaan bahasa dalam iklan harus bersifat persuasi agar mampu menarik perhatian konsumen untuk membeli produk yang ditawarkan. 
Bahasa yang dipakai pengiklan juga harus sesuai dengan konteks (pengiklan, produk yang diiklankan, dan waktu pembuatan iklan).

Bentuk penggunaan bahasa yang dipakai pengiklan dalam memasarkan produknya kepada masyarakat dapat berupa kalimat pernyataan, pertanyaan, maupun perintah atau permintaan. Penggunaan bentuk tuturan tersebut sesuai atau berdasarkan keinginan dari si pengiklan. Kemudian, fungsi penggunaan bahasa yang terdapat di dalam iklan (advertise) juga tidak terlepas dari bentuk penggunaan bahasa yang dipakai pengiklannya, seperti kalimat pertanyaan berfungsi menanyakan, kalimat pernyataan berfungsi untuk menyatakan, dan kalimat perintah atau permintaan berfungsi untuk memerintah atau meminta. Fungsi penggunaan bahasa tersebut ditujukan kepada konsumen atau masyarkat. Sedangkan, strategi penggunaan bahasa yang lazim atau pada umumnya dalam menyampaikan tuturan seperti halnya pengiklan saat mempromosikan produknya kepada konsumen adalah menggunakan dua jenis strategi yaitu strategi langsung dan strategi tidak langsung.

Youtube dipilih sebagai sumber data dalam penlitian ini karena selain salah satu situs web di internet (interconnection-networking) yang menyediakan berbagai macam video mulai dari video klip lagu sampai film, serta video-video yang dibuat pengguna youtube itu sendiri juga dipakai oleh beberapa kalangan orang sebagai media dalam menawarkan produknya kepada masyarakat seperti, iklan minuman, makanan, kecantikan, produk-produk rumah tangga, dan berbagai macam iklan lainnya. Oleh karena itu, peneliti bisa dengan mudah mengunduh beberapa iklan (lebih khususnya iklan minuman) yang telah diunggah di youtube sebagai data dalam penelitian ini.

\section{Rumusan Masalah}

Berdasarkan latar belakang masalah di atas, maka dapat dirumuskan masalahnya sebagai berikut. (1) Bagaimana bentuk penggunaan bahasa dalam iklan minuman di youtube? (2) Bagaimana fungsi penggunaan bahasa dalam iklan minuman di youtube? (3) Bagaimana strategi penggunaan bahasa dalam iklan minuman di youtube?

\section{Tujuan Penelitian}

Tujuan Penelitian ini adalah untuk mendapatkan gambaran objektif tentang: (1) bentuk penggunaan bahasa dalam iklan minuman di youtube, (2) fungsi penggunaan bahasa dalam iklan minuman di youtube, dan (3) strategi penggunaan bahasa dalam iklan minuman di youtube.

\section{Manfaat Hasil Penelitian}

Ada dua manfaat yang diharapkan dalam penelitian ini, yaitu sebagai berikut. (1) Manfaat teoritis: a) Secara teoritis, hasil penelitian ini diharapkan dapat digunakan sebagai bahan ajar terutama pada perguruan tinggi khususnya ilmu pragmatik tentang bentuk, fungsi, dan strategi tindak tutur dan dapat memberikan gambaran tentang penggunaan bahasa dalam bertindak tutur lebih khsusnya dalam dunia periklanan. b) Dilihat dari segi teoritis, maka penelitian ini akan dapat mengupas dan menggunakan beberapa teori yang berkaitan dengan penggunaan bahasa dalam konteks tuturan sehingga diperoleh masukan teori yang lebih relevan dengan pembahasan yang dilakukan. 
(2) Manfaat praktis: a) Manfaat bagi peneliti selanjutnya, penelitian ini diharapkan dapat bermanfaat bagi peneliti dalam memahami bentuk, fungsi, dan strategi penggunaan bahasa serta dapat memberikan pendapat, ide atau gagasan kepada teman-teman dan juga memperdalam ilmu linguistik khusunya pragmatik. Selanjutnya, penelitian ini juga sebagai bahan rujukan dalam melakukan penelitian khususnya penelitian penggunaan bahasa seperti "Penggunaan Bahasa dalam Iklan Minuman di Youtube."b) Manfaat bagi guru, penelitian ini diharapkan dapat menjadi acuan bagi seorang guru dalam penggunaan bahasa untuk menyampaikan materi kepada peserta didik agar peserta didik dapat dengan mudah memahami materi yang diajarkan. Serta tambahan wawasan pengetahuan penggunaan bahasa dalam pelajaran lebih khususnya pelajaran bahasa Indonesia, sehingga dapat diketahui berbagai jenis contoh dan model penggunaan bahasa yang mungkin belum pernah diajarkan di sekolah atau digunakan guru-guru di sekolah pada saat kegiatan belajar mengajar berlangsung. c) Manfaat bagi siswa, penelitian ini diharapkan bermanfaat untuk siswa, agar siswa memiliki gambaran tentang bentuk, fungsi, dan strategi penggunaan bahasa sehingga siswa atau peserta didik dapat memahami apa yang disampaikan oleh guru pada saat kegiatan belajar mengajar berlangsung di kelas.

\section{KAJIAN PUSTAKA}

\section{Bentuk Penggunaan Bahasa}

Bentuk penggunaan bahasa merupakan wujud dari sebuah tuturan yang disampaikan kepada lawan bicara. Bentuk penggunaan bahasa yang dilakukan oleh penutur terhadap mitra tutur pada umumnya dapat berbentuk kalimat berita/pernyataan, kalimat pertanyaan, dan kalimat perintah. Bentuk-bentuk penggunaan bahasa itu disampaikan atau digunakan dalam sebuah peristiwa tutur dengan maksud-maksud tertentu sesuai dengan keinginan penutur.

Searle (Rahardi, 2005:36) menggolongkan tindak tutur ilokusi ke dalam lima macam bentuk tuturan yang masing-masing memiliki fungsi komunikatif. Kelima macam bentuk tuturan yang menunjukkan fungsi itu dapat dirangkum sebagai berikut:

1. Asertif (Assertives),

yakni bentuk tuturan yang mengikat penutur pada kebenaran proposisi yang diungkapkan, misalnya menyatakan (stating), memberikan kasaksian, mengeluh (complaining), dan mengklaim (claiming).

\section{Direktif (Directives),}

yakni bentuk tuturan yang dimaksudkan penuturannya untuk membuat pengaruh agar si mitra tutur melakukan tindakan, misalnya, memesan (orderin), memerintah (commanding), memohon (requesting), menasehati (advising), dan merekomendasi (recommending).

3. Ekspresif (Expressives),

adalah bentuk tuturan yang berfungsi untuk menyatakan atau menunjukkan sikap psikologis penutur terhadap suatu keadaan, misalnya berterima kasih (thanking), memberi selamat (congratulating), meminta maaf (pardoning), menyalahkan (blambing), memuji (praising), berbelasungkawa (condoling).

4. Komisif (Commissives), 
yakni bentuk tuturan yang berfungsi untuk menyatakan janji atau penawaran, misalnya berjanji (promising), bersumpah (vowing), dan menawarkan sesuatu (offering).

\section{Deklarasi (Declarations),}

yaitu bentuk tuturan yang menghubungkan isi tuturan dengan kenyataan, misalnya berpasrah (resigning), memecat (dismissing), menbaptis (chistening), memberi nama (naming), mengangkat (appointing), mengucilkan (excommicating), dan menghukum (sentencing).

\section{Fungsi Penggunaan Bahasa}

Fungsi penggunaan bahasa merupakan maksud atau kegunaan dari sebuah tuturan yang disampaikan kepada mitra tutur. Fungsi penggunaan bahasa itu bisa berupa menginformasikan atau memberitahukan, meminta, memerintah, menyarankan, menawarkan, meyakinkan, dan sebagainya. Fungsi atau maksud tersebut dapat diketahui dari tuturan yang disampaikan penutur.

Fungsi atau maksud dari sebuah tuturan pada umumnya yaitu berdasarkan penggunaan bentuk kalimatnya, seperti kalimat berita berfungsi untuk memberitakan atau memberitahukan, kalimat tanya berfungsi untuk menanyakan, dan kalimat perintah berfungsi untuk memerintah.

Chaer dan Agustina (2010:15) menjelaskan bahwa fungsi-fungsi bahasa itu dapat dilihat dari sudut penutur, pendengar, topik, kode, dan amanat pembicara. Kemudian, Searle (Rahardi, 2005:36) juga mengemukakan fungsi tindak tutur yang di bagi dalam lima bentuk tuturan, seperti (a) asertif yang berfungsi untuk menyatakan, memberikan kesaksian, mengeluh, dan mengklaim, (b) direktif berfungsi untuk memesan, memerintah, memohon, menasihati, dan menyarankan, (c) ekspresif berfungsi untuk berterima kasih, memberi selamat, meminta maaf, menyalahkan, memuji, berbelasungkawa, (d) komisif berfungsi untuk berjanji, bersumpah, dan menawarkan sesuatu, dan (e) deklaratif berfungsi untuk berpasrah, memecat, menbaptis, memberi nama, mengangkat, mengucilkan, dan menghukum.

\section{Strategi Penggunaan Bahasa}

Strategi penggunaan bahasa merupakan cara atau metode si penutur dalam menyampaikan tuturannya kepada mitra tutur. Strategi penggunaan bahasa meliputi strategi langsung dan strategi tidak langsung. Strategi langsung artinya struktur (dalam hal ini bentuk tuturan) dengan fungsi (maksud) memilki hubungan langsung, sedangkan strategi tidak langsung artinya struktur atau bentuk tuturan dengan maksud tuturan tidak memiliki hubungan langsung. Agar lebih jelas, berikut penjelasan para ahli mengenai strategi penggunaan bahasa yang meliputi strategi langsung dan strategi tidak langsung.

Strategi tindak tutur adalah cara-cara yang digunakan partisipan tutur dalam mengekspresikan tindak atau fungsi tindak tutur menggunakan tuturan tertentu. Wijana, (1996:13) mengisyaratkan bahwa strategi penyampaian tindak atau fungsi tindak tutur dapat diwujudkan dengan tuturan bermodus deklaratif, interogatif, dan imperatif (bermakna literal atau nonliteral dan langsung atau tidak langsung).

Yule (2014:95), mengatakan bahwa apabila ada hubungan langsung antara struktur (bentuk) dengan fungsi (maksud) dari sebuah tuturan maka disebut tindak tutur langsung. Sedangkan, apabila ada hubungan tidak langsung antara struktur 
(bentuk) dengan fungsi (maksud) dari sebuah tuturan maka disebut tindak tutur tidak langsung.

Berdasarkan uraian di atas dapat dismpulkan bahwa strategi tindak tutur dibedakan menjadi dua yaitu strategi langsung dan tidak langsung. Strategi langsung merupakan strategi penyampaian tindak tutur menggunakan tuturan yang bentuknya mempunyai makna sama (atau mirip) dengan maksud pengutaraannya. Sedangkan, strategi tidak langsung merupakan strategi yang penyampaian tindak tutur menggunakan tuturan yang bentuknya mempunyai makna yang tidak sama dengan maksud penuturannya.

\section{METODE PENELITIAN}

Pendekatan penelitian yang digunakan dalam penelitian ini adalah pendekatan kualitatif. Pendekatan kualitatif dianggap peneliti sebagai pendekatan yang tepat digunakan pada objek penelitian ini, karena pada dasarnya metode pendekatan kualitatif memaparkan data secara deskriptif berupa kata-kata tertulis atau lisan dari objek yang diteliti sehingga menemukan kebenaran yang dapat diterima oleh akal sehat manusia.

Data penelitian ini adalah berupa kutipan kata, frase, dan kalimat tentang bentuk penggunaan bahasa, fungsi penggunaan bahasa, dan strategi penggunaan bahasa dalam iklan minuman di youtube. Sedangkan, sumber data dalam penelitian ini diperoleh dari iklan minuman di youtube dengan cara diunduh. Ada tujuh iklan minuman yang menjadi sampel dalam penelitian ini, yaitu (1) iklan Aqua, (2) iklan Dancow Cokelat Fortigro, (3) iklan Kopi Luwak Gula, (4) iklan Kopi Torabika Susu, (5) iklan Sprite, (6) iklan Vit Levite, dan (7) iklan Top Coffe.

Instrumen penelitian merupakan alat bantu yang dipilih dan digunakan peneliti dalam melakukan penelitiannya untuk mengumpulkan data agar kegiatan tersebut sistematis dan dipermudah olehnya. Kedudukan peneliti dalam penelitian kualitatif adalah sebagai isntrumen artinya instrumen penelitian yang utama dalam penelitian ini adalah peneliti sendiri (human instrument). Menurut Moleong (2001:103) peneliti sebagai instrumen pertama berarti peneliti bertindak sebagai perencanaan, pelaksana pengumpulan data, analisis, penafsiran, dan akhirnya menjadi pelapor hasil penelitian. Sedangkan, instrumen pendukung berupa buku sebagai refrensi, laptop sebagai pengetik laporan, serta alat tulis sebagai alat mencatat.

Dalam penelitian bahasa, Mahsun (2007: 92) menjelaskan bahwa proses pengumpulan atau penyediaan data dilakukan dengan metode simak karena cara yang digunakan untuk memperoleh data dilakukan dengan menyimak penggunaan bahasa. Istilah menyimak ini tidak hanya berkaitan dengan bahasa lisan tetapi juga penggunaan bahasa secara tertulis. Metode ini memiliki teknik dasar yang berwujud teknik sadap. Teknik sadap disebut sebagai teknik dasar dalam metode simak karena pada hakikatnya penyimakan diwujudkan dengan penyadapan. Perlu ditekankan bahwa menyadap penggunaan bahasa yang dimaksudkan menyangkut penggunaan bahasa baik secara lisan maupun tulisan. Setelah melakukan penyadapan, kemudian dilanjutkan pada teknik catat. Teknik catat adalah teknik lanjutan yang dilakukan ketika telah melakukan tenik sadap pada penggunaan bahasa. Jika tidak dilakukan 
pencatatan, peneliti dapat juga melakukan perekaman ketika menerapkan metode simak.

\section{HASIL DAN PEMBAHASAN}

Hasil penelitian ini mencakup tiga hal, yaitu (1) bentuk penggunaan bahasa dalam iklan minuman di youtube, (2) fungsi penggunaan bahasa dalam iklan minuman di youtube, dan (3) strategi penggunaan bahasa dalam iklan minuman di youtube.

\section{Penggunaan Bahasa dalam Iklan Minuman di Youtube.}

Bentuk penggunaan bahasa dalam iklan minuman di youtube merupakan bentuk tuturan yang dipakai pengiklan dalam menawarkan atau memasarkan produknya (minuman) ke masyarakat atau konsumen. Bentuk penggunaan bahasa terdiri dari lima yaitu asertif, direktif, ekspresif, komisif, dan deklaratif. Tetapi, berdasarkan data yang telah dikumpulkan peneliti dari lima bentuk penggunaan bahasa itu hanya dua bentuk penggunaan bahasa yang kerap dipakai pengiklan dalam iklan minuman yaitu bentuk asertif dan direktif.

1) Bentuk Asertif

Bentuk penggunaan bahasa asertif merupakan bentuk tuturan yang mengikat penutur pada kebenaran proposisi yang diungkapkan, misalnya menyatakan (stating), memberikan kasaksian, meyakinkan, mengeluh (complaining), dan mengklaim (claiming).

Paparan datanya sebagai berikut:

\section{Iklan Aqua}

Konteks:

Dua orang gadis yang sedang menonton konser musik Sandy Sandoro. Setelah konser selesai, dua gadis itu beranjak pulang. Masih berada di sekitar tempat konser, si gadis A melihat sosok pria yang mirip dengan Sandy Sandoro dari tampak belakang. Tanpa basa-basi si gadis A langsung mengajak foto berdua bersama pria yang dikiranya Sandy

Tuturan dalam iklan Aqua:

A : Keren banget ya tadi Sandy.

B : Iya. Mau aqua? Dari tadi belum minum loh.

A : Nanti aja. (Melihat sosok pria yang tampila nnya seperti Sandy Sandoro) ha ? Sandy selfie bareng dong.

(Setelah selesai berfoto, si gadis A baru menyadari ternyata pria yang diajaknya selfie tadi bukan Sandy Sandoro. Sedangkan, Sandy Sandoro yang asli sedang ber-selfie dengan si gadis $B$ )

$\mathrm{N}$ : Kurang minum menurunkan konsentrasi dan fokus.

A : (Sambil memberikan tatapan kosong) ada aqua?

(Keterangan: $A=$ Artis 1, $B=$ Artis 2, dan $N=$ Narator).

Dari kutipan di atas tuturan yang dikaji peneliti adalah tuturan yang disampaikan narator "kurang minum menurunkan konsentrasi dan fokus" karena 
tuturan itu mengandung fungsi informatif dan persuasif berkaitan dengan produk yang ditawarkan kepada penonton atau konsumen.

Bentuk penggunaan bahasa yang disampaikan oleh narator dalam iklan di atas adalah asertif berupa menyatakan. Tuturan tersebut berisikan informasi tentang manfaat air mineral aquayang dapat meningkatkan konsentrasi dan fokus. Tuturan yang disampaikan narator dalam iklan di atas menggunakan kalimat pernyataan.

\section{Iklan Dancow Cokelat Fortigro}

Konteks:

Seorang anak laki-laki yang meminta kepada ibunya untuk membuatkannya susu dancow cokelat. Tetapi, pada saat ia menghampiri ibunya di ruang tamu ternyata ibunya sedang menjamu tamu yang juga seorang ibu yang datang dengan anak perempuannya. Karena malu dan takut dibilang manja oleh anak perempuan yang sebaya dengannya itu, ia pun membuat sendiri susu dancow cokelat tanpa bantuan ibunya.

Tuturan dalam iklan Dancow:
A : Ma, mau dancow dong!
B : Mau dancow nak?
A :(Melihat ke arah anak perempuan yang seumuran dengannya, sambil tersenyum) bikin sendiri aja.

$\mathbf{N}$ :Makin sedikit kekhawatiran, makin banyak pengalaman yang ia dapatkan. Dancow cokelat fortigro. Lebih sedikit gula tapi lebih banyak nutrisi untuk tumbuh besar.

A : Mau? (Menatap ke arah anak perempuan teman ibunya sambil menunjukan susu dancow cokelat di tangannya)

(Keterangan: $A=$ anak laki-laki, $B=I b u$, dan $N=$ Narator)

Dari kutipan di atas bentuk penggunaan bahasa yang disampaikan narator dalam iklan dancow cokelat fortigrodi atasadalah asertif berupa menyatakan. Tuturan yang disampaikan narator dalam iklan dancow cokelat fortigro menggunakan kalimat pernyataan yang berisikan informasi tentang keunggulan dari dancow cokelat fortigro yaitu lebih sedikit gula dan lebih banyak nutrisi untuk pertumbuhan atau perkembangan anak. Tuturan yang disampaikan narator dalam iklan di atas menggunakan kalimat pernyataan.

\section{2) Bentuk Direktif}

Bentuk penggunaan bahasa direktif merupakan bentuk tuturan yang dimaksudkan penuturannya untuk membuat pengaruh agar si mitra tutur melakukan tindakan, misalnya, memesan (orderin), memerintah (commanding), memohon (requesting), menasehati (advising), dan merekomendasi (recommending).

Paparan datanya sebagai berikut:

\section{Iklan Kopi Luwak Gula}

Konteks:

Tiga orang laki-laki yang sedang duduk dan mengobrol tentang kenikmatan kopi di sebuah kedai kopi.

Tuturan dalam iklan Kopi Luwak Gula:

A : (Menyeruput kopi) ah, kopi apa ini? Enggak enak. 
B : Lugu aja! Luwak gula, luwak kopi hitam + gula.

A : Dari kopi luwak yang terkenal itu?

$\mathrm{C}$ : Yang bintangnya Le Min Ho kan?

B :Luwak kopi hitam + gula alami. Biji kopi dipanggang perlahan dan merata.

(Sambil menyeruput kopi luwak) ah, sekali luwak?

A dan C : Aroma kopi luwaknya, nyampe di mulut (tertawa).

$B$ : Kalau ngopi, lugu pilihannya. Luwak gula. Luwak kopi hitam + gula. (Keterangan: $A=$ Artis 1, $B=$ Artis 2, dan $C=$ Artis 3)

Dari kutipan di atas tuturan yang menjadi kajian peneliti adalah tuturan terakhir yang disampaikan oleh si B (Artis 2) "kalau ngopi, lugu pilihannya. Luwak gula. Luwak kopi hitam + gula”. Tuturan tersebut mengandung fungsi persuasif dan informatif berkaitan dengan produk yang diiklankan.

Bentuk penggunaan bahasa yang disampaikan oleh artis B dalam kutipan iklan kopi luwak gula di atas adalah direktif berupa menyarankan. Hal ini dapat dilihat dari kalimat awal yang disampaikan pengiklan (B), "kalau ngopi, lugu pilihannya." Tuturan yang disampaikan si B dalam iklan tersebut berisikan saran kepada penonton yaitu jika ingin merasakan kenikmatan kopi, kopi luwak gula lah pilihan yang tepat untuk dikonsumsi.

\section{Fungsi Penggunaan Bahasa dalam Iklan Minuman di Youtube}

Fungsi penggunaan bahasa dalam iklan minuman di youtube merupakan maksud atau kegunaan dari tuturan yang disampaikan pengiklan dalam menawarkan produknya (minuman) kepada masyarakat. Berdasarkan data yang telah dikumpulkan, ditemukan tiga fungsi penggunaan bahasa dalam iklan minuman yaitu memberitahukan atau menginformasikan, menyarankan, dan meyakinkan.

1) Fungsi Penggunaan Bahasa untuk Menginformasikan

Paparan datanya sebaga berikut:

\section{Iklan Vit Levite}

Konteks:

Iklan ini dibintangi oleh lima orang artis yang diantaranya adalah tiga orang perempuan dan dua orang laki-laki. Kelima orang ini merasa haus karena lelah berjalan di siang hari. Lalu, mereka berhenti di sebuah lapak yang menjual minuman dingin.

Tuturan dalam iklan Vit Lavite:

A : Minum dulu yuk!

B, C, dan D : Ayo (secara bersamaan).

$\mathrm{E}$ : Mau dong.

(Artis A mengambil minuman Vit Levite sedangkan keempat artis yang lain mengambil minuman yang bermerek lain)

B, C, D, dan E : (Sambil menatap ke arah si A yang sedang minum vit levite secara bersamaan) oh... Vit Levite.

E : Gimana rasanya? (sambil berlari menuju si A yang kemudia diikuti oleh tiga orang temannya)

A : Pas manisnya. Rasanya merosot di tenggorokan (sambil berteriak).

$\mathrm{N}$ : Vit Levite. Kesegaran air vit dengan sentuhan rasa buah yang manisnya pas, merosot di tenggorokan. 
(Keterangan: $A=$ Artis 1, $B=$ Artis 2, $C=$ Artis 3, $D=$ Artis 4, $E=$ Artis 5, dan $N=$ Narator)

Fungsi penggunaan bahasa yang disampaikan pengiklan $(\mathrm{N})$ dalam iklan Vit Levite di atas adalah bermaksud memberitahukan atau menginfomasikan kepada penonton atau konsumen bahwa minuman Vit Levite memilki sentuhan rasa buah yang manisnya pas dan sangat terasa di tonggorokan. Jadi, dapat dikatakan dengan singkat fungsi penggunaan bahasa yang dipakai pengiklan di atas adalah untuk memberitahukan atau menginformasikan.

2) Fungsi Penggunaan Bahasa untuk Menyarankan

\section{Iklan Kopi Luwak Gula}

Konteks:

Tiga orang laki-laki yang sedang duduk dan mengobrol tentang kenikmatan kopi di sebuah kedai kopi.

Tuturan dalam iklan Kopi Luwak Gula:

A : (Menyeruput kopi) ah, kopi apa ini? Enggak enak.

B : Lugu aja! Luwak gula, luwak kopi hitam + gula.

A : Dari kopi luwak yang terkenal itu?

$\mathrm{C}$ : Yang bintangnya Le Min Ho kan?

B :Luwak kopi hitam + gula alami. Biji kopi dipanggang perlahan dan merata.

(Sambil menyeruput kopi luwak) ah, sekali luwak?

A dan C : Aroma kopi luwaknya, nyampe di mulut (tertawa).

B : Kalau ngopi, lugu pilihannya. Luwak gula. Luwak kopi hitam + gula. (Keterangan: $A=$ Artis 1, $B=$ Artis 2, dan C=Artis 3)

Fungsi penggunaan bahasa yang disampaikan pengiklan dalam iklan Kopi Luwak Gula di atas adalah bermaksud menyarankan kepada penonton atau masyarakat bahwa jika ingin merasakan kenikmatan dari minuman kopi, kopi luwak gula lah pilihan yang tepat untuk dikonsumsi. Hal itu, dapat dilihat dari tuturan yang disampaikan pengiklan si B "kalau ngopi, lugu pilihannya." Jadi, dapat juga dikatakan dengan singkat bahwa fungsi penggunaan bahasanya adalah untuk menyarankan.

3) Fungsi Penggunaan Bahasa untuk Meyakinkan

\section{Iklan Kopi Torabika Susu}

Konteks:

Iklan ini dibintangi oleh artis Chicco Jerikho yang seolah-olah bekerja di sebuah kedai kopi.

Tuturan dalam iklan Kopi Torabika Susu:

"Gue pecinta kopi. Soal kopi susu. Ini torabika susu (sambil menunjukan kopi torabika susu). Kopinya 100\% mantap. Susu fullcreamnya 100\% gurih. 100\% mantapnya kopi, $100 \%$ gurihnya susu menyatu di torabika susu. Luar biasa. Sempurna. Gue enggak pernah bercanda soal kopi susu. Lo harus coba! Torabika susu, 100\% mantapnya kopi. 100\% gurihnya susu."

(Keterangan: tuturan dalam iklan kopi torabika susu disampaikan oleh artis Chicco Jerikho).

Fungsi penggunaan bahasa yang dipakai pengiklan dalam iklan Kopi Torabika Susu di atas adalah bermaksud meyakinkan penonton atau masyarakat bahwa Kopi 
Torabika Susu lah pilihan yang paling tepat untuk dikonsumsi, hal itu dapat dilihat dari tuturan yang disampaikan pengiklan yaitu "100\% mantapnya kopi, 100\% gurihnya susu menyatu di torabika susu. Luar biasa. Sempurna. Gue enggak pernah bercanda soal kopi susu. Lo harus coba!" atau dapat juga dikatakan dengan singkat bahwa fungsi penggunaan bahasanya adalah untuk meyakinkan.

\section{Strategi Penggunaan Bahasa dalam Iklan Minuman di Youtube}

Strategi penggunaan bahasa dalam iklan minuman merupakan cara penyampaian tuturan pengiklan dalam menawarkan produknya (minuman) kepada masyarakat atau konsumen. Strategi penggunaan bahasa terdiri dari dua yaitu strategi tidak langsung dan strategi langsung.

\section{1) Strategi Tidak Langsung}

Strategi tidak langsung dalam sebuah tuturan terjadi apabila struktur (bentuk) dan fungsi (maksud) tidak memiliki hubungan secara langsung.

Paparan datanya sebagai berikut:

\section{Iklan Sprite}

Konteks:

Iklan ini disampaikan oleh artis komedian Cak Lontong. Dalam membintangi iklan ini Cak Lontong mencoba memengaruhi penonton dengan menggunakan tuturan yang sedikit bersifat humoris agar penonton ikut merasakan kenikmatan dari minuman sprite.

Tuturan dalam iklan sprite:

"Hey guys, ayo berpikir jernih. Apa iya dengan mencampur sendiri es batu, rasa lemon, dan gelembung bisa seenak dan se-nyegerin segelas sprite? Boleh aja dicoba, tapi nyatanya susah. Menurut kamu info ini gak penting? Nyatanya kamu jadi nontonin iklan ini selama lebih dari 20 detik. Dan sekarang kamu jadi haus dan pengen minum sprite. Sprite. Nyatanya nyegerin."

(Keterangan: iklan sprite di atas disampaikan oleh Cak Lontong)

Strategi penggunaan bahasa yang disampaikan pengiklan dalam iklan Sprite di atas adalah strategi tidak langsung, karena tuturan yang disampaikan pengiklan menggunakan tuturan asertif berupa meyakinkan tetapi tuturan itu bukan sekadar meyakinkan penonton atau konsumen melalui informasi yang disampaikan berkaitan dengan produk yang diiklankan melainkan bermaksud agar penonton atau konsumen membeli produk tersebut dengan cara memberitahukan kelebihan dari produk yang ditawarkan.

2) Strategi Langsung

Strategi langsung dalam sebuah tuturan terjadi apabila ada hubungan langsung antara bentuk dan fungsi tuturan yang disampaikan.

Paparan datanya sebagai berikut:

\section{Iklan Kopi Luwak Gula}

Konteks:

Tiga orang laki-laki yang sedang duduk dan mengobrol tentang kenikmatan kopi di sebuah kedai kopi.

Tuturan dalam iklan Kopi Luwak Gula:

A : (Menyeruput kopi) ah, kopi apa ini? Enggak enak.

B : Lugu aja! Luwak gula, luwak kopi hitam + gula. 
A : Dari kopi luwak yang terkenal itu?

$\mathrm{C}$ : Yang bintangnya Le Min Ho kan?

B :Luwak kopi hitam + gula alami. Biji kopi dipanggang perlahan dan merata.

(Sambil menyeruput kopi luwak) ah, sekali luwak?

A dan C : Aroma kopi luwaknya, nyampe di mulut (tertawa).

$B$ : Kalau ngopi, lugu pilihannya. Luwak gula. Luwak kopi hitam + gula. (Keterangan: $A=$ Artis 1, $B=$ Artis 2, dan $C=$ Artis 3)

Strategi penggunaan bahasa yang dipakai pengiklan (B) dalam iklan Kopi Luwak Gula di atas adalah strategi langsung, karena dalam menyampaikan tuturan pengiklan (B) secara langsung menyuruh atau meminta secara halus kepada penonton atau masyarakat untuk mengonsumsi kopi luwak gula, hal itu dapat dilihat dari tuturan yang disampaikan pengiklan yaitu “...Kalau ngopi, Lugu pilihannya....”

\section{PENUTUP}

\section{Kesimpulan}

Pertama, berdasarkan pembahasan yang telah dilakukan, dari tujuh iklan minuman yang telah dianalisis peneliti ditemukan enam iklan yang menggunakan bentuk penggunaan bahasa asertif dan hanya satu iklan minuman yang menggunakan bentuk penggunaan bahasa direktif. Jadi, dapat disimpulkan bahwa bentuk penggunaan bahasa yang dominan yang dipakai pengiklan dalam iklan minuman di youtube adalah bentuk penggunaan bahasa asertif. Bentuk penggunaan bahasa asertif adalah bentuk penggunaan bahasa yang efektif dipakai pengiklan dalam menawarkan suatu komoditas (barang atau jasa) kepada konsumen. Bentuk penggunaan bahasa asertif itu dapat berupa menyatakan, meyakinkan, mengeluh, mengklaim, dan sebagainya.

Kedua, berdasarkan pembahasan yang telah dilakukan, dari tujuh iklan minuman yang telah dianalisis peneliti ditemukan empat iklan minuman yang fungsi penggunaan bahasanya adalah untuk memberitahukan atau menginformasikan, dua iklan minuman yang fungsi penggunaan bahasanya adalah untuk meyakinkan, dan satu iklan minuman yang fungsi penggunaan bahasanya adalah untuk menyarankan. Jadi, dapat disimpulkan bahwa fungsi penggunaan bahasa yang dominan dalam iklan minuman di youtube adalah untuk menginformasikan atau memberitahukan tentang kelebihan atau keunggulan dari produk yang diiklankan kepada penonton atau konsumen.

Ketiga, berdasarkan pembahasan yang telah dilakukan, dari tujuh iklan minuman di youtube yang telah dianalisis peneliti, ditemukan lima iklan minuman yang strategi penggunaan bahasanya adalah strategi tidak langsung dan dua iklan minuman yang strategi penggunaan bahasanya menggunakan strategi langsung. Jadi, dapat disimpulkan bahwa strategi penggunaan bahasa yang dominan dalam iklan minuman di youtube adalah strategi tidak langsung. Penggunaan strategi tidak langsung dalam menyampaikan sebuah tuturan saat mengiklankan suatu komoditas (barang atau jasa) kepada masyarakat merupakan salah satu cara yang efektif digunakan, karena dengan menggunakan strategi tidak langsung pengiklan hanya menyampaikan kelebihan dan manfaat dari produk yang diiklankan tanpa harus 
memerintah atau meminta secara langsung kepada konsumen untuk membeli produk yang ditawarkan.

\section{DAFTAR PUSTAKA}

Chaer, Abdul. 2012. Linguistik Umum. Jakarta: Rineka Cipta, cet.4.

Chaer, Abdul dan Leonie Agustina. 2010. Sosiolinguistik Perkenalan Awal. Jakarta: Rineka Cipta

Effendi. 2012. Panduan Bahasa Indonesia dengan Baik dan Benar. Jakarta: Pustaka Jaya

Mahsun. 2007. METODE PENELITIAN BAHASA: Tahapan Strategi, Metode, dan Tekniknya. Jakarta: PT RajaGrafindo Persada.

Moleong, Lexy J. 2001. Metodologi Penelitian Kualitatif. Bandung: Remaja Rosdakarya.

Rahardi, Kunjana. 2005. Pragmatik Kesantunan Imperatif Bahasa Indonesia. Jakarta: Erlangga.

Suyanto. 2015. Membenah, Memelihara, dan Menggunakan Bahasa Indonesia Secara Benar, Kajian Historis-Teoritis dan Praktik Tulis. Yogyakarta: Graha Ilmu

Wijana, I Dewa Putu. 1996. Dasar-Dasar Pragmatik. Yogyakart: ANDI.

Yule, George. 2014. Pragmatik. Diterjemahkan oleh Indah Fajar Wahyuni. Yogyakarta: Pustaka Pelajar. Cet. 2. 